\title{
In the Name of the European Club of Liberal Democracies: On the Identity, Mandate and National Buffering of the ECtHR's Case Law*
}

Armin von Bogdandy / Laura Hering ${ }^{* * * * *}$

The ECtHR is under observation. The Copenhagen Declaration has called on the Convention States to evaluate its case law in order to decide on further reform. But what are the yardsticks for such an evaluation? We submit that they can be found in the source of the ECtHR's democratic legitimacy, one the one hand, and in the challenges it faces, on the other. Thus, the present contribution argues that the Court speaks In the name of the European club of liberal democracies and that its greatest challenge is continuing to do so in a credible manner.

* Translation by Fabian Eichberger. The text was published in German in Juristenzeitung 74 (2020), 53-63. A short version was published as an editorial in 58 Der Staat 2019, 1-5. It is based on a presentation given at the High-Level Expert Conference on the ECHR system, Kokkedal, 31 October - 2 November 2018. We would like to thank the Tuesday Round as well as Christina Binder, Raffaela Kunz, Angelika Nußberger, Mateja Steinbrück Platise and Ingo Venzke for their valuable criticism.

* Director, Max Planck Institute for Comparative Public Law and International Law; Professor for Public Law, Goethe University Frankfurt.

**: Senior Research Fellow, Max Planck Institute for Comparative Public Law and International Law. 


\section{Agenda}

European human-rights protection and its most important institution, the European Court of Human Rights (ECtHR), face a wide range of challenges. ${ }^{1}$ Of these, the procedural backlog may be the least. More importantly, the legitimacy of some judges is contentious: increasingly authoritarian governments are in power in a number of Convention States and many judgments are met with considerable resistance. ${ }^{2}$ Moreover, wellestablished courts such as the German Bundesverfassungsgericht and the Italian Corte Costituzionale seek to limit the ECtHR's law-making authority. ${ }^{3}$ In their Copenhagen Declaration of April 2018, the Convention States even formally stipulated that recent ECtHR case law should be evaluated. ${ }^{4}$ It is not too far-fetched to interpret this announcement as an expression of dissatisfaction as well as a warning.

1 On the challenges, see e.g., Council of Europe Steering Committee for Human Rights (2016), "The Longer-Term Future of the System of the European Convention on Human Rights", available at https://rm.coe.int/the-longer-term-future-of-the -system-of-the-european-convention-on-hum/1680695ad4, accessed 27 October 2019; Çalı, B. (2018), "Coping with Crisis: Wither the Variable Geometry in the Jurisprudence of the European Court of Human Rights", Wisconsin International Law Journal 35(2), 237-276, 240 et seq.

2 On the attacks, see Madsen, M.R. (2016), "The Challenging Authority of the European Court of Human Rights: From Cold War Legal Diplomacy to the Brighton Declaration and Backlash", Law and Contemporary Problems 79(1), 141-178, 167 et seq.; Soley, X. and Steininger, S. (2018), "Parting ways or lashing back? Withdrawals, backlash and the Inter-American Court of Human Rights", International Journal of Law in Context 14(2), 237-257, 237 et seq.; Breuer, M. (ed.) (2019), Principled Resistance to ECtHR Judgments - A New Paradigm?. Heidelberg: Springer.

3 Italian Constitutional Court, Decision No. 49 (26 March 2015); BVerfG 148, 296 (Bundesverfassungsgericht); see infra, IV.

4 Copenhagen Declaration, passed at the High Level Conference of 12/13 April 2018, available at http://rm.coe.int/copenhagen-declaration/16807b915c, accessed 6 December 2019, para. 41. On the Declaration, see Polakiewicz, J. and SuominenPicht, I. (2018), "Aktuelle Herausforderungen für Europarat und EMRK: Die Erklärung von Kopenhagen (April 2018), das Spannungsverhältnis zwischen EMRK und nationalen Verfassungen und die Beteiligung der EU an dem europäischen Menschenrechtskontrollmechanismus”, Europäische Grundrechte-Zeitschrift 45(4), 383-390, 383 et seq.; Ulfstein, G. and Føllesdal, A. (2018), "Copenhagen - much ado about little?”, EJIL: Talk!, 14 April, available at https://www.ejiltalk.org/copenhagenmuch-ado-about-little/, accessed 6 December 2019. 
Navigating through troubled waters requires steady orientation. One fixed star that has been underused thus far is the democratic legitimation of ECtHR rulings. 5 But democratic legitimation begs the following question: in whose name does the ECtHR actually decide? The core argument of this contribution is that the law and the Court's path thus far can be condensed into the postulation that the ECtHR speaks In the name of the European club of liberal democracies. At the same time, the Strasbourg Court's greatest challenge is for this postulation to remain credible.

The first part of this article explains why the democratic legitimacy of the ECtHR is an issue (II. A.). It then justifies the postulation In the name of the European club of liberal democracies as an answer (II. B.). The second part shows how this postulation materializes in the mandate of the Court. For many decades, the Court discharged this mandate by supporting the rights revolution in Europe, embedding constitutional courts in a European discourse and contributing to the transformation of post-authoritarian states (III. A.). In light of authoritarian tendencies in some Convention States, the mandate is now acquiring more dimensions, in particular the defense of the club's self-image as well as the need to support constitutional democracy in those States. This requires a new evaluation of the Court (III. B. 1.), in particular its jurisprudence on state of emergency (III. B. 2.), core rights (III. B. 3.), abuse of rights (III. B. 4.), and exhaustion of domestic remedies (III. B. 5.). Moreover, to secure its own future we argue that the Court should further develop its doctrine of the margin of appreciation (III. B. 6.). This, in turn, calls for a modification of its mandate and a buffering of its judicial law-making. The German Bundesverfassungsgericht and the Italian Corte Costituzionale provide ideas for this evolution (IV.).

5 On the various legitimacy-enhancing mechanisms, see von Bogdandy, A. and Venzke, I. (2014), In whose Name? A Public Law Theory of International Adjudication. Oxford: Oxford University Press, 156 et seq. 


\section{The Democratic Legitimacy of the ECtHR}

\section{A. The Issue}

The ECtHR does not fit into the traditional role of an international court that serves merely as an intergovernmental dispute-settlement body. Its decisions regularly concern controversial domestic issues. ${ }^{6}$ Moreover, it not only claims authority over the decided dispute but demands that all national courts follow its decisions. ${ }^{7}$ Last but not least, the ECtHR is even reminiscent of a constitutional court, as it controls whether domestic legislators respect individual rights. ${ }^{8}$

The ECtHR wields no coercive power, but it nevertheless exercises public authority. ${ }^{9}$ Its decisions exert considerable pressure. Thus, the Committee of Ministers of the Council of Europe monitors the implementation of ECtHR judgments under Article 46 para. 2 European Convention on Human Rights (ECHR), and the $14^{\text {th }}$ Additional Protocol has added an infringement procedure under Article 46 para. 4 ECHR, which was recently invoked for the first time. ${ }^{10}$ Other Convention States expect a losing State to abide by the judgments of the Court. ${ }^{11}$ Even domestic law

6 See, e.g., Hirst v. United Kingdom (No. 2), ECtHR Application No. 74025/01, Judgment of 6 October 2005, on the political rights of convicts; Zaunegger v. Germany, ECtHR Application No. 22028/04, Judgment of 3 December 2009, on child custody.

7 Cf. Ireland v. United Kingdom, ECtHR Application No. 5310/71, Judgment of 18 January 1978, para. 154; Guzzardi v. Italy, ECtHR Application No. 7367/76, Judgment of 6 November 1980, para. 86; Rantsev v. Cyprus and Russia, ECtHR Application No. 25965/04, Judgment of 7 January 2010, para. 197; G.I.E.M. S.R.L. a.o. v. Italy, ECtHR Application No. 1828/06, Judgment (Merits) of 28 June 2018, para. 252.

8 For the constitutional function, $c f$. Grabenwarter, C. (2015), "The European Convention on Human Rights: Inherent Constitutional Tendencies and the Role of the European Court of Human Rights" In: A. von Bogdandy and P. Sonnevend (eds), Constitutional crisis in the European constitutional area. Oxford: C.H. Beck / Hart / Nomos, 257-274; Nußberger, A. (2019), "Die Europäische Menschenrechtskonvention - eine Verfassung für Europa?”, Juristenzeitung 74(9), 421-428; Walter, C. (1999), "Die Europäische Menschenrechtskonvention als Konstitutionalisierungsprozeß”, Zeitschrift für ausländisches öffentliches Recht und Völkerrecht 59, 961-983, 962 et seq.

9 On the multiple functions and public authority of international courts, see von Bogdandy and Venzke, supra note 5, 5-18, 101-119.

10 Mammadov v. Azerbaijan, ECtHR Application No. 15172/13, Judgment of 29 May 2019.

11 Expressly mentioned in the Copenhagen Declaration, supra note 4, paras 19 et seq. 
often requires compliance with the European human-rights system; $;^{12}$ national courts, specific human rights institutions, ${ }^{13}$ and an often-powerful public stand ready to scrutinize this compliance.

Such authority raises questions of legitimacy, including from a democratic point of view. ${ }^{14}$ This is a particularly vulnerable flank of the Court, because it regularly opposes democratically elected institutions, i.e., institutions with the strongest possible legitimacy, whereas its own democratic mandate is not obvious. While many national courts claim democratic legitimacy in the first words of their judgments, which begin with In the name of the people, ${ }^{15}$ the ECtHR remains silent. ${ }^{16}$

\section{B. The Club of Liberal Democracies}

Which prefatory expression could evoke a democratic legitimation similar to national courts' In the name of the people? In whose name does the ECtHR actually decide? ${ }^{17}$ It could refer to the Convention and use In the name of the European Convention on Human Rights - which would be akin to a national court using In the name of the law. However, this would ignore the fact that it is not the law as such but the underlying parliamentary decision that provides the real source of democratic legitimacy.

This insight as to the real source leads to the national ratifications of the Convention. Accordingly, one could consider, following the classical understanding of international law, whether the ECtHR decides In the

12 For the position of the ECtHR in Member States' domestic law, see Keller, H. and Stone Sweet, A. (eds) (2008), A Europe of Rights. The Impact of the ECHR on National Legal Systems. Oxford: Oxford University Press, 31 et seq.

13 GA Res. 48/134 of 20 December 1993, U.N. Doc. A/RES/48/134.

14 On the importance of democratic legitimacy for the judiciary, Voßkuhle, A. and Sydow, G. (2002), "Die demokratische Legitimation des Richters", Juristenzeitung 57(14), 673-682. Critically, Torres, A. (2017), "In Nobody's Name: A Checks and Balances Approach to International Judicial Independence”, MPIL Research Paper (3), available at https://papers.ssrn.com/sol3/papers.cfm?abstract_id=2924435, accessed 31 October 2019.

15 See, e.g., $\$ 25$ para. 4 BVerfGG (Act on the Bundesverfassungsgericht); Art. 101 para. 1 of the Constitution of the Italian Republic; Art. 454 of the French Code of Civil Procedure.

16 Cf. the fundamental critique of Bellamy, R. (2014), "The Democratic Legitimacy of International Human Rights Conventions: Political Constitutionalism and the European Convention on Human Rights", European Journal of International Law 25(4), 1019-1042.

17 Bellamy has also already tried to define the "constituency" of the ECtHR, see ibid. 
name of the State parties to the dispute. This may be appropriate for the International Court of Justice. Yet it certainly does not apply to the Strasbourg Court where the litigants, as a rule, are not two States but one State and one individual, who is often also a citizen of the involved State. What then?

The democratic legitimacy of the Strasbourg Court is based first and foremost on the ratification of the Convention by all contracting parties. It accordingly decides In the name of all the high contracting parties. The holistic all expresses a fundamental feature: a judgment of the ECtHR not only adjudicates the disputed case, but also serves a common interest of all Convention States, to wit, "Human rights and the rule of law in Europe", as stated in recital 2 of the Copenhagen Declaration. The ECHR thus leaves the traditional bilateralism of international law far behind; its decisions pursue a community interest.

The expression, In the name of all the high contracting parties can be condensed further. The ECHR not only overcomes the traditional bilateralism of international law but also transcends that regime's traditional agnosticism with respect to the political system of States. A Convention State must be liberal and democratic. ${ }^{18}$ Certainly not all the States met all the requirements when they joined. However, such States were accepted with the obligation to further develop their democratic and rule of law structures in accordance with the Convention. ${ }^{19}$

The demand to be liberal and democratic is not abstract but takes shape through its threefold opposition to the totalitarian systems of the Axis powers, Soviet communism, ${ }^{20}$ and authoritarian regimes such as the Greece of the Obrists. ${ }^{21}$ Today it rests on the consolidated practice of the

18 See the Preamble and Article 3 of the Statute of the Council of Europe. For the concept of democracy in the case law of the ECtHR, see Zand, J. (2017), "The Concept of Democracy and the European Convention on Human Rights", University of Baltimore Journal of International Law 5(2), 195-227; Lautenbach, G. (2014), The Concept of the Rule of Law and the European Court of Human Rights. Oxford: Oxford University Press, 193 et seq.

19 See, for example, regarding Russia: Parliamentary Assembly of the Council of Europe, Application by Russia for membership of the Council of Europe, Opinion 192 (1996), No. 7, available at https://assembly.coe.int/nw/xml/XRef/Xref-XM L2HTML-EN.asp?fileid=13932\&lang=en, accessed 31 October 2019.

20 Madsen, M.R. (2007), "From Cold War Instrument to Supreme European Court: The European Court of Human Rights at the Crossroads of International and National Law and Politics”, Law \& Social Inquiry 32(1), 137-159.

21 On the exclusion procedure against Greece in 1969 in accordance with Article 8 of the Statute of the Council of Europe, Richter, H.A. (2013), Griechenland 1950 1974. Zwischen Demokratie und Diktatur. Ruhpolding: Verlag Franz Philipp Rutzen, 323 et seq. 
Strasbourg organs. It encompasses the effective protection of a broad range of fundamental rights, political pluralism and a functioning separation of powers, including independent courts. ${ }^{22}$ This meaning of liberalism, it bears mentioning, has nothing to do with left leaning or neo-liberal ideologies. Instead, it contrasts with what Victor Orbán is projecting as an "illiberal democracy" 23 .

The preamble to the Convention states that human rights and fundamental freedoms can best be safeguarded "by an effective political democracy". It even embraces a corresponding Europe-wide legal culture as "common heritage of political traditions, ideals, freedom and the rule of law". According to travaux préparatoires, the Convention was created not only to protect the people against dictatorships but also to strengthen the resistance against creeping attempts to undermine the democratic way of life a significant objective in today's context. ${ }^{24}$ As a result, we can replace "high contracting parties" with "liberal, democratic States". Thus we arrive at a more appropriate formula: the ECtHR, we submit, decides In the name of European liberal democratic States.

The Convention, furthermore, not only concerns the State apparatus and the formal organisation of public authority. It is also a groundbreaking treaty because it overcomes traditional international law in a third respect. By equipping individuals with rights and creating an individual complaint mechanism, it transforms private agents into transnational actors. Moreover, the Convention often addresses the individual as citizen and political subject. Securing democratic rights is one of the Court's most important lines of case law. ${ }^{25}$ Just consider the Court's rulings on freedom of political association under Article 11 ECHR, ${ }^{26}$ freedom of political expression

22 On the independence of the courts, Campbell and Fell v. United Kingdom, ECtHR Application No. 7819/77, Judgment of 28 June 1984, para. 78.

23 Orbán, V. (2018), "Speech at the $29^{\text {th }}$ Bálványos Summer Open University and Student Camp", July 28, available at https:/www.kormany.hu/en/the-prime-minist er/the-prime-minister-s-speeches/prime-minister-viktor-orban-s-speech-at-the-29thbalvanyos-summer-open-university-and-student-camp, accessed 31 October 2019.

24 See Council of Europe (1979), Collected edition of the "Travaux préparatoires" of the European Convention on Human Rights. Vol. 5: Legal Committee, Ad Hoc Joint Committee, Committee of Ministers, Consultative Assembly (23 June - 28 August 1950). The Hague / Boston / London: Martinus Nijhoff.

25 See supra note18.

$26 C f$. the case law on the ban of political parties, Vona $v$. Hungary, ECtHR Application No. 35943/10, Judgment of 9 July 2013, para. 58; Freedom and Democracy Party (Özdep) v. Turkey, ECtHR Application No. 23885/94, Judgment of 8 December 1999, para. 37. 
under Article $10 \mathrm{ECHR}^{27}$ and the right to free elections under Article 3 of the First Additional Protocol, ${ }^{28}$ as well as Articles 3 and 8 of the Statute of the Council of Europe. This inclusion of citizens is an important achievement of the Strasbourg system and should be manifested in the introductory formula. It is no coincidence that national courts do not adjudicate In the name of the State but in the name of the people or of the republic.

We can articulate this dimension by abbreviating the formula In the name of European liberal democratic States into In the name of European liberal democracies. Integrating States within democracies allows citizens to become part of that expression. One should note the grammatical plural democracies, moreover. It is significant because the Court does not speak in the name of some abstract idea of a political order. Rather, the formula underlines that the democratic legitimacy of the Court derives from the democratically organized peoples of the Convention States.

Finally, the formula should reflect the fact that the democratic legitimacy of the ECtHR is a common achievement of European democracies. It has an important collective dimension, not least because the Court's judges are elected by the Parliamentary Assembly of the Council of Europe. ${ }^{29}$ This term $c l u b$ in the formula expresses, therefore, that European democracies have come together under the Statute of the Council of Europe and the Convention to pursue objectives that they cannot achieve on their own. The most important one is a regional human rights system that safeguards their concurrent constitutional systems. ${ }^{30}$ To this end, the Convention States have established common, independent institutions vested with public authority, including the ECtHR, whose judges they

27 On freedom of expression, see Handyside v. UK, ECtHR Application No. 5493/72, Judgment of 7 December 1976, para. 49; also, Frowein, J.A. (2008), "Meinungsfreiheit und Demokratie", Europäische Grundrechte-Zeitschrift 35(2), 117-121.

28 See Natale, V. (2006), "Le droit à des élections libres ou la construction d'un véritable ordre démocratique européen", Revue trimestrielle des droits de l'homme 68, 939-972.

29 Von Bogdandy, A. and Krenn, C. (2015), "On the Democratic Legitimacy of Europe's Judges: A Principled and Comparative Reconstruction of the Selection Procedures” In: M. Bobek (ed.), Selecting Europe's Judges. Oxford: Oxford University Press, 162-180.

30 Cf. Bates, E. (2010), The Evolution of the European Convention on Human Rights: From its Inception to the Creation of a Permanent Court of Human Rights. Oxford: Oxford University Press, 5; Greer, S. (2006), The European Convention on Human Rights: Achievements, Problems and Prospects. Cambridge: Cambridge University Press, 56 et seq. 
jointly elect in a parliamentary procedure. The term "club" is well established in this respect. ${ }^{31}$

\section{The Mandate to Protect the Democratic Rule of Law}

\section{A. The Development of the Mandate}

If the ECtHR speaks In the name of the European club of liberal democracies, what should it say? The answer can only be partially derived through the canon of legal methods with which the Convention is to be interpreted. These methods hardly ever determine a decision, especially in the case of open norms such as human rights. ${ }^{32}$ What is more significant is how ECtHR judges, their national colleagues, other national and international authorities and, last but not least, the democratic public understand the mandate of the ECtHR. The current understanding of the mandate can be summarized as ascribing an active, sometimes even transformative role to the ECtHR in ensuring that the club is actually one of liberal democracies.

It can by no means be taken for granted, but is rather an outstanding and surprising achievement, that the ECtHR today has such a mandate to support and develop the European club of liberal democracies. ${ }^{33}$ This becomes clear in retrospect. The ECHR was initially understood as a

31 The Council of Europe describes itself as "club of democracies", see Parliamentary Assembly of the Council of Europe (1995), Official Report of Debates. Strasbourg: Council of Europe Publishing, 45; Cf. also Carrillo Salcedo, J.A. (2003), El Convenio Europeo de Derechos Humanos. Madrid: Tecnos, 14; Weber, F. (2016), "Die Europäische Menschenrechtskonvention und die Türkei - Zum Notstand sowie zur Möglichkeit der Wiedereinführung der Todesstrafe", Die Öffentliche Verwaltung" 21(22), 921-929; Gioia, A. (2011), "The Role of the European Court of Human Rights in Monitoring Compliance with Humanitarian Law in Armed Conflict" In: O. Ben-Naftali (ed.), International Humanitarian Law and International Human Rights Law. Oxford: Oxford University Press, 201-249, 202.

32 Kelsen, H. (1929), "Wesen und Entwicklung der Staatsgerichtsbarkeit", Veröffentlichungen der Vereinigung der Deutschen Staatsrechtslehrer 5, 30-88, 31; Möllers, C. (2012), "Individuelle Legitimation: Wie rechtfertigen sich Gerichte?" In: A. Geis, F. Nullmeier and C. Daase (eds), Der Aufstieg der Legitimitätspolitik. Baden-Baden: Nomos, 398-418, 403 et seq.

33 On the development, see Bates, E. (2011), "The Birth of the European Convention on Human Rights" In: J. Christoffersen and M.R. Madsen (eds), The European Court of Human Rights between Law and Politics. Oxford: Oxford University Press, $17-42$. 
response to "Soviet-style communism"34. Since those States were not under the jurisdiction of the ECtHR, the Court had little to do. Its first president famously doubted whether it was relevant at all. ${ }^{35}$ Jochen Frowein likened the ECHR of this day to a "sleeping beauty" 36 .

Only gradually did the ECtHR assume a role in supporting what is described in the United States as the rights revolution: the substantial expansion of individual rights. ${ }^{37}$ When individual rights protection became an important issue in Western societies, many Convention States did not have a good basis for this. They often lacked a modern catalogue of rights and had few institutions fit for constitutional adjudication. This gap provided an opportunity for the Court and the former Human Rights Commission to step in and begin supporting the rights revolution in a variety of countries, thereby taking on a task comparable to that of a constitutional court in this respect. ${ }^{38}$ The legal instruments used to accomplish this task included the dynamic or evolutionary interpretation of the ECHR ${ }^{39}$ and the authority of its decisions beyond the case at hand. ${ }^{40}$ Once it had ventured onto this path, the Court gained the support of a large number of

34 Grabenwarter, C. and Pabel, K. (2016), Europäische Menschenrechtskonvention ( $6^{\text {th }}$ ed.). Basel: Helbing Lichtenhahn Verlag, $\$ 1$ para. 1; Grote, R. (2013), "Entstehungs- und Rezeptionsgeschichte der EMRK" In: O. Dörr, R. Grote and T. Marauhn (eds), EMRK/GG Konkordanzkommentar (2 ${ }^{\text {nd }}$ ed.). Tübingen: Mohr Siebeck, para. 10.

35 Rolin, H. (1965), "Has the European Court of Human Rights a Future", Howard Law Journal 11, 442-451.

36 Frowein, J.A. (1984), "European Integration through Fundamental Rights", Michigan Journal of Law Reform 18(1), 5-27, 8.

37 Ibid., 7: "legal revolution". Regarding the USA, see Epp, C.R. (1998), The Rights Revolution. Lawyers, Activists, and Supreme Courts in Comparative Perspective. Chicago: The University of Chicago Press.

38 See for Austria: Grabenwarter, C. (2008), “Österreich” In: A. von Bogdandy, P. Cruz Villalón and P.M. Huber (eds), Handbuch Ius Publicum Europaeum. Vol. II: Offene Staatlichkeit - Wissenschaft vom Verfassungsrecht. Heidelberg: C.F. Müller, $\$ 20$, paras 64 et seq.; for the Netherlands, Wessel, R.A. and van de Griendt, W.E., "Niederlande" In: ibid, $\$ 19$, paras 52 et seq.

39 Frowein, J.A. (2005), "Die evolutive Auslegung der EMRK” In: T. Marauhn (ed.), Recht, Politik und Rechtspolitik in den internationalen Beziehungen. Tübingen: Mohr Siebeck, 1-13; Bernhardt, R. (1999), "Evolutive Treaty Interpretation, Especially of the European Convention of Human Rights", German Yearbook of International Law 42, 11-26.

40 Cf. Copenhagen Declaration, supra note 4, paras 3, 8, 14, 26 et seq.; Arnardóttir, O.M. (2017), "Res Interpretata, Erga Omnes Effect and the Role of the Margin of Appreciation in Giving Domestic Effect to the Judgments of the European Court of Human Rights", European Journal of International Law 28(3), 819-843. 
actors and thus acquired a key role for liberal democracy in Europe. ${ }^{41}$ Today it is identified with this mandate, as is confirmed by the Copenhagen Declaration. ${ }^{42}$

The mandate is somewhat different for certain States like Germany or Italy, which have a proud and functioning constitutional court. These courts have independently developed the protection of individual rights that runs largely in parallel to the Strasbourg system. Accordingly, for these States the role of the ECtHR consists of embedding their courts in the European context. ${ }^{43}$ Thanks to Strasbourg decisions, the German and Italian protections of fundamental rights are embedded in a Europe-wide human rights system which has a common vocabulary, a common doctrine and even first signs of a common legal culture. ${ }^{44}$ This certainly creates a specific type of conflict, since it requires a visible control by the Strasbourg Court of the proud constitutional courts of these States in an area they consider the core of their mandate. ${ }^{45}$ So far, however, such conflicts have been successfully handled. The key terms here are dialogue and joint responsibility. ${ }^{46}$

The third aspect of this mandate to promote liberal democracy arose after the fall of the Berlin Wall, when the Strasbourg Court began to accompany Central and Eastern European countries in their transformation. ${ }^{47}$ New lines of jurisprudence emerged that restricted national autonomy far more intensively than before. One could point, for example, to the decisions on the structure of national judicial systems, to rulings on "tran-

41 Cf. Mowbray, A. (1999), "ECtHR and Democracy", Public Law, 703-725; on the transformation of the ECtHR system, see Roca, F.G. (2018), "La transformación del Convenio Europeo de Derechos Humanos", Revista General de Derecho Constitucional 28, 1-60.

42 Copenhagen Declaration, supra note 4, para. 2.

43 On embeddedness, see Helfer, L. (2008), "Redesigning the European Court of Human Rights: Embeddedness as a Deep Structural Principle of the European Human Rights Regime”, European Journal of International Law 19(1), 125-159.

44 Häberle, P. (1991), "Gemeineuropäisches Verfassungsrecht", Europäische Grundrechte-Zeitschrift 18(12-13), 261-274.

45 Regarding this conflict, see Paris, D. (2017), "Allies and Counterbalances - Constitutional Courts and the European Court of Human Rights: A Comparative Perspective", Zeitschrift für ausländisches öffentliches Recht und Völkerrecht 77, 623-649.

46 See Copenhagen Declaration, supra note 4, paras 6 et seq., 33, 36 et seq.

47 Hofmann, M. (2009), Von der Transformation zur Kooperationsoffenheit?. Berlin / Heidelberg: Springer, 86 et seq., 182 et seq., 248 et seq., 315 et seq., 395 et seq.; Motoc, I. and Ziemele, I. (eds) (2016), The Impact of the ECHR on Democratic Change in Central and Eastern Europe. Cambridge: Cambridge University Press. 
sitional justice" or to pilot judgments that addressed structural deficits. ${ }^{48}$ All this significantly increased the breadth and depth of Strasbourg's significance and influence. Nevertheless, most observers, as reflected in the Copenhagen Declaration, regard this case law as part of the Court's mandate. ${ }^{49}$

\section{B. The Mandate in Times of Crises}

The jurisprudence of the Court has successfully supported the rights revolution in European democracies, the European embedding of national constitutional courts and the transformation of Central and Eastern European countries. This means the ECtHR is in a position to credibly render decisions In the name of the European club of liberal democracies. However, this is by no means guaranteed and the club is at a crossroads. The Court must choose between two paths, both of which lead into difficult terrain.

In some countries, the human rights situation has deteriorated drastically, ${ }^{50}$ to the extent that the credentials of some States as liberal democracies can be challenged. These States threaten the identity of the club. Of course, almost every club has difficult, even ill-suited members, without this endangering the club's identity. At a certain point, however, such members begin to shape this common identity due to their number, visibility, weight, strategy or influence on how the club is perceived externally. It is now becoming questionable whether the Strasbourg Court can continue to adjudicate In the name of the European club of liberal democracies.

At these crossroads, the club can, on one path, choose to defend its identity as a club of liberal democracies - although this would affect its identity, since its previous culture of consensus can hardly be maintained. On

48 The first pilot procedure concerned the so-called Bug River case from Poland: Broniowski v. Poland, ECtHR Application No. 31443/96, Judgment of 22 June 2004; See also Broniowski $v$. Poland (friendly settlement), ECtHR Application No. 31443/96, Judgment of 28 September 2005. On the emergence see Sadurski, W. (2009), "Partnering with Strasbourg: Constitutionalisation of the European Court of Human Rights, the Accession of Central and East European States to the Council of Europe, and the Idea of Pilot Judgments”, Human Rights Law Review 9(3), 397-453.

49 See Copenhagen Declaration supra note 4, paras 14, 17; cf. also Committee of Ministers, Resolution Res(2004)3 on judgments revealing an underlying systemic problem, (12 May 2004), available at https://search.coe.int/cm/Pages/result_details .aspx?ObjectId=09000016805dd190 (last visited 1 November 2019).

50 See, in this context, Copenhagen Declaration supra note 4, para. 16. 
the other path, it could accept that those problematic members co-determine its identity ${ }^{51}$ - in which case, the club would probably not dissolve but instead find itself with a very different identity. Without doubt, the Strasbourg institutions could continue to be useful. The United Nations Security Council, the United Nations Human Rights Council, and the International Court of Justice are certainly valuable, for instance. But they are not institutions of a club of liberal democracies.

If one understands the ECtHR's mandate as one of contributing to liberal democracy in Europe, then it should choose the first path. The Court's more recent jurisprudence, accordingly, should be evaluated in this light.

\section{Court Authority in Times of Crises}

Before analysing individual lines of case law, a preliminary point needs to be clarified. Every court must acquire authority, because only authority can help it fulfil its mandate. ${ }^{52}$ Whether a losing State complies with its judgments is an important indicator about the authority of the ECtHR. ${ }^{53}$ This means that the losing State not only pays any awarded compensation but also rectifies the established infringement and even adapts its internal legal situation to conform with the ruling. This process is often described as "implementation" or "compliance". 54

51 Stewart, S. (2019), "Der Europarat und Russland. Glaubwürdigkeit verlangt konsequente Entscheidungen”, Stiftung Wissenschaft und Politik - Aktuell 29(May), available at https://www.swp-berlin.org/publikation/der-europarat-und-russland/, accessed 1 November 2019.

52 On this challenge, Alter, K.J., Helfer, L.R. and Madsen, M.R. (2018), "How Context Shapes the Authority of International Courts" In: K.J. Alter et al. (eds), International Court Authority. Oxford: Oxford University Press, 24-56.

53 See Polzin, M. (2018), "Der verrechtlichte Ausnahmezustand - Art. 15 EMRK und die Rolle des Europäischen Gerichtshofs für Menschenrechte”, Zeitschrift für ausländisches öffentliches Recht und Völkerrecht 78, 635-669, 650.

54 von Staden, A. (2018), Strategies of Compliance with the European Court of Human Rights: Rational choice within normative constraints. Philadelphia: University of Pennsylvania Press. 
In this respect, the ECtHR has to contend with considerable difficulties. ${ }^{55}$ The great importance it attaches to compliance with judgments, in particular the implementation of general measures, can easily lead it to be timid towards governments whose self-portrayal relies on their opposition to Europe. If one were to link judicial authority to this indicator first and foremost, one would place it in the hands of such governments and discourage the Court from intervening in what is probably the greatest challenge to European public order. This would make no sense. Therefore, evaluating the Court's operation requires a different approach.

This statement does not question that the implementation of the Court's rulings is legally mandatory. One should welcome, accordingly, that the Copenhagen Declaration leaves no doubt in this respect. ${ }^{56}$ But while compliance and implementation remain the most important yardsticks for evaluating the losing State, criteria beyond compliance and implementation become important for assessing the Court. In particular, one should look at the impact of its case law. ${ }^{57}$

The focus on impact re-directs our attention to the question whether the Strasbourg Court's jurisprudence allows the club to maintain its identity as one of liberal democracies in a credible manner. It also entails inquiring into whether the case law supports domestic forces that are committed to liberal democracy in difficult States. An impressive example of this is the Inter-American Court of Human Rights (IACtHR). Although this court struggles with even greater problems of compliance, ${ }^{58}$ its jurisprudence has given human rights an active role in often dramatic contexts of violence, exclusion and inequality. Today, political discourses and major disputes in Latin America are conducted in the language of human rights. This is from where the IACtHR draws its authority, and this is where it has found its

55 Cf., e.g., Committee of Ministers (2019), Annual Report 2018. Supervision of the execution of judgments and decisions of the European Court of Human Rights. Strasbourg: Council of Europe, 71 et seq, available at https://rm.coe.int/annual-report-2018/16 8093f3da, accessed 1 December 2019.

56 See, in this context, Copenhagen Declaration, supra note 4, para. 19 et seq.

57 This approach was especially developed for the Inter-American system. See Parra Vera, O. (2017), "The Impact of Inter-American Judgments by Institutional Empowerment” In: A. von Bogdandy et al. (eds), Transformative Constitutionalism in Latin America: The Emergence of a New Ius Commune. Oxford: Oxford University Press, 357-376.

58 Anzola, S.I., Sánchez, B.E. and Urueña E. (2015), Después Del Fallo. El Cumplimiento De Las Decisiones Del Sistema Inter-Americano De Derechos Humanos: Una Propuesta De Metodología. Bogota: Universidad de los Andes (series "Justicia Global" $11)$. 
mandate. ${ }^{59}$ One should also remember the Helsinki Final Act, which since 1975 has supported Central and Eastern European human rights movements in their eventually successful struggle for freedom.

Today the Strasbourg Court can assist domestic forces through relevant decisions. This remains promising, not least since none of those States has turned totalitarian: there remain independent judges, opposition groups, and civil society forces. ${ }^{60}$ The most meaningful yardstick for evaluating a human rights court in such a constellation is not the compliance of a government, therefore, but that court's ability to position human rights as a powerful argument in institutional procedures and public debates. ${ }^{61}$ Supranational jurisprudence can thus promote national self-healing through domestic processes. ${ }^{62}$

Whether the Strasbourg Court is able to do so provides a yardstick for evaluating its jurisprudence. This applies in particular to the more recent case law on state of emergency (2), core rights (3), abuse of rights (4) and exhaustion of domestic remedies (5).

\section{Limits of the Case Law on State of Emergency}

The ECtHR has drawn red lines with its recent case law on state of emergency. Article 15 ECHR allows Convention States to suspend certain Convention rights in extreme situations. ${ }^{63}$ In recent years, this Article has

59 See von Bogdandy, A. (2019), "The Transformative Mandate of the Inter-American System”, MPIL Research Paper 16, 1-15, available at https://papers.ssrn.com/sol3/pa pers.cfm?abstract_id=3463059, accessed 6 December 2019; for a comparison of the European and the Inter-American system of human rights protection, see Vasel, J. (2017), Regionaler Menschenrechtsschutz als Emanzipationsprozess. Berlin: Duncker \& Humblot.

60 On the ECtHR's influence on the developments in Eastern European States, see the references in supra note 47.

61 See Huneeus, A. (2016), "Constitutional Lawyers and the Inter-American Court's Varied Authority", Law and Contemporary Problems 79(1), 179-207.

62 With regards to Hungary: Sonnevend, P. (2017), "Preserving the Acquis of Transformative Constitutionalism in Times of Constitutional Crisis: Lessons from the Hungarian Case" In: von Bogdandy et al., supra note 57, 123-145, 140 et seq.

63 On this, see Ashauer C. (2007), "Die Menschenrechte im Notstand", Archiv des Völkerrechts 47(3), 400-431. 
gained considerable importance due to the derogation declarations of Ukraine ${ }^{64}$, France ${ }^{65}$ and Turkey ${ }^{66}$.

The Court is certainly cautious in this sensitive area and allows the Convention States a wide margin of appreciation in assessing a dangerous situation and classifying it as an emergency. ${ }^{67}$ It has begun to tighten the requirements, ${ }^{68}$ however, in response to criticism. ${ }^{69}$ The Convention States continue to have a wide margin of appreciation in the assessment of these exigencies, but the Court now conducts an increasingly detailed proportionality test. ${ }^{70}$ This test takes into account the significance of the derogated right of the Convention, the general situation surrounding the state of emergency and its duration. ${ }^{71}$ On several occasions, the ECtHR has found that the defendant State breached the requirements of Article 15

64 Council of Europe (2015), "Ukraine derogation from European Convention on Human Rights” (Press Release), 10 June, available at https:/www.coe.int/en/web/ portal/news-2015/-/asset_publisher/9k8wkRrYhB8C/content/ukraine-derogation-f rom-european-convention-on-human-rights, accessed 6 December 2019.

65 Council of Europe (2015), "France informs Secretary General of Article 15 Derogation of the European Convention on Human Rights" (Press Release), 25 November, available at https:/www.coe.int/en/web/secretary-general/news/-/asset _publisher/EYlBJNjXtA5U/content/france-informs-secretary-general-of-article-15derogation-of-the-european-convention-on-human-rights, accessed 6 December 2019.

66 Council of Europe (2016), "Secretary General receives notification from Turkey of its intention to temporarily suspend part of the European Convention on Human Rights" (Press Release), 21 July, available at https:/www.coe.int/en/web/portal/ne ws-2016/-/asset_publisher/StEVosr24HJ2/content/secretary-general-receives-notific ation-from-turkey-of-its-intention-to-temporarily-suspend-the-european-conventio n-on-human-rights, accessed 6 December 2019.

67 For the first application, see Ireland v. United Kingdom, supra note 7, para. 207. See also Krieger, H. (2013), "Notstand" In: Dörr, Grote and Marauhn, supra note 34, 417-443, para. 12.

68 See also Harris, D. et al. (eds) (2018), Law of the European Convention on Human Rights ( ${ }^{\text {th }}$ ed.). Oxford: Oxford University Press, 821 et seq.

69 See, e.g., Chrysler, E. (1994), "Brannigan and McBridge v. UK: A New Direction on Article 15 Derogations under the European Convention on Human Rights?", Revue Belge de Droit International 27(2), 603-631, 628 et seq.; Gross, O. and Ní Aoláin, F. (2001), "From Discretion to Scrutiny: Revisiting the Application of the Margin of Appreciation Doctrine in the Context of Article 15 of the European Convention on Human Rights", Human Rights Quarterly 23(3), 625-649, 637 et seq.

70 For this assessment, see Polzin, supra note 53, 643 et seq.

71 Brannigan and McBride v. United Kingdom, ECtHR Application No. 14553/89, Judgment of 25 May 1993, para. 43; Aksoy v. Turkey, ECtHR Application No. 21987/93, Judgment of 18 December 1996, para. 68. 
ECHR - such as in Aksoy v. Turkey ${ }^{72}$, A. a.o. v. United Kingdom ${ }^{73}$, as well as in Altan v. Turkey ${ }^{74}$ and Alpay v. Turkey ${ }^{75}$.

The current state of emergency in Turkey poses major challenges for the ECtHR. ${ }^{76}$ Clearly, this is a situation when Strasbourg is most needed to stand up for the protection of human rights. However, the ECtHR risks its judgments not being observed or the Convention being denounced if it relies on a more progressive approach to Article 15 ECHR and imposes sweeping restrictions on the discretion of the Convention States. It also risks exposing itself to accusations of practicing politics instead of legal interpretation. ${ }^{77}$

The ECtHR has approached this dilemma firstly by exercising restraint. It did not make any general remarks on Article 15 ECHR, which was possible because the Turkish Constitutional Court had already issued the corresponding judgments. Particularly in the Altan and Alpay cases, the Court remained very cursory. ${ }^{78}$ Secondly, the Strasbourg Court has drawn red lines by defining the limits of government restriction on freedom of expression: in the Altan and Alpay cases, the ECtHR for the first time examined Article 10 ECHR within the framework of a state of emergency. It is true that it did not expressly deal with the requirements of the exigencies of the situation under Article 15 ECHR. However, the explanations point to a narrow interpretation of the restrictions, one under which the right to freedom of expression pursuant to Article 10 ECHR can only be restricted in absolutely exceptional cases. ${ }^{79}$

Furthermore, the ECtHR recognizes that measures taken in a state of emergency might not only serve to address a threat but might also aim to weaken or even abolish democratic structures. ${ }^{80}$ It emphasizes the impor-

72 Ibid.

73 A and others $v$. United Kingdom, ECtHR Application No. 3455/05, Judgment of 19 February 2009.

74 Mebmet Hasan Altan v. Turkey, ECtHR Application No. 13237/17, Judgment of 20 March 2018.

75 Şahin Alpay v. Turkey, ECtHR Application No. 16538/17, Judgment of 20 March 2018.

76 See Weber, supra note 31, 925 et seq.

77 Ibid., 925.

78 Altan $v$. Turkey, supra note 74, para 140, 213; Alpay v. Turkey, supra note 75, paras 119, 183. However, in $A$ and others $v$. UK, supra note 73, the reasoning comprised paras $182-190$.

79 Altan v. Turkey, supra note 74, paras 206, 207; Alpay v. Turkey, supra note 75, paras 177, 178. See also Polzin, supra note 53, 667.

80 Ibid., 654. 
tance of freedom of expression for a functioning democracy and points out in an obiter dictum that a state of emergency must not serve as a pretext for restricting the freedom of political debate. Emergency measures must remain committed to the protection of democracy. ${ }^{81}$ Moreover, it does not grant the Member States any margin of appreciation if they are accused of violating non-derogable rights through killings, torture or inhuman treatment.

\section{Core Rights}

The case law on freedom of expression likewise reflects the core rights case law of the ECtHR, which defines essential and therefore red lines of liberal democracies. The Court treats core rights differently from a doctrinal vantage point. While its mandate to support the rights revolution in Europe has led to a broad understanding of most Convention rights, the costs of this approach, combined with a context-open proportionality test, are wellknown and have been countered by the concept of core rights. ${ }^{82}$

Accordingly, Convention rights consist of various elements, some of which are more important and therefore more worthy of protection than others. ${ }^{83}$ This differentiation can be found not only in the case law of the ECtHR but also under the European Charter of Fundamental Rights ${ }^{84}$ and in various national constitutions. When it comes to core rights, the Court draws red lines by dispensing with the usual balancing style of argumentation and instead adopts a more categorical reasoning. ${ }^{85}$

The protection of core rights is particularly evident in the prohibitions of torture (Article 3 ECHR) and slavery (Article 4 ECHR), where the ECtHR completely dispenses with balancing. ${ }^{86}$ The prohibition of State killings (Article 2 para. 2 ECHR) is also interpreted in light of the protec-

81 Altan v. Turkey, supra note 74, para. 210; Alpay v. Turkey, supra note 75, 180.

82 Cf. von Bernstorff, J. (2011), "Kerngehaltsschutz durch den UN-Menschenrechtsausschuss und den EGMR: Vom Wert kategorialer Argumentationsformen”, Der Staat 50(2), 165-190.

83 Leijten, I. (2018), Core socio-economic rights and the European Court of Human Rights. Cambridge: Cambridge University Press, 2, 11.

84 European Charter of Fundamental Rights, Article 52, para. 1.

85 Von Bernstorff, supra note 82, 172 et seq.

86 See Gäfgen v. Germany, ECtHR Application No. 22978/05, Judgment of 30 June 2008, para. 69. 
tion of core rights, allowing for only narrow exceptions that cannot be part of proportionality assessments. ${ }^{87}$

Categorical forms of argumentation become more difficult for human rights that are subject to broadly defined exceptions, such as Articles 8 to 11 ECHR. But it is precisely here that the doctrine of core contents proves helpful. Expressions of opinion that are critical of the government can only be restricted if they constitute an incitement to violence. ${ }^{88}$ Political debate is highly protected due to its key role in a democratic society. ${ }^{89}$ The core rights oriented jurisprudence of the ECtHR thus constitutes a further element in the red lines that substantiate the European club of liberal democracies.

\section{The Abuse of Rights}

Another instrument to protect what is essential to the $c l u b$ and to respond to crises in the democratic rule of law is the prohibition of abuse of rights. Article 18 ECHR stipulates that restrictions may "only be imposed for the intended purposes".

For a long time, this provision appeared to be largely irrelevant, ${ }^{90}$ and the requirements for presenting evidence regarding the motives of State authorities were strict. ${ }^{91}$ This changed in 2004, however, when the ECtHR concluded for the first time that Article 18 in conjunction with Article 5 ECHR had been breached. ${ }^{92}$ Further cases followed, mainly concerning

87 McCann and others v. United Kingdom, ECtHR Application No. 18984/91, Judgment of 27 September 1995, para. 150.

88 See, e.g., Zana v. Turkey, ECtHR Application No. 18954/91, Judgment of 25 November 1997; Sürek and Özdemir v. Turkey, ECtHR Application Nos. 23927/94 and 24277/94, Judgment of 8 July 1999.

89 According to the ECtHR's jurisprudence, the freedom of political debate is at the core of democratic societies, as envisaged by the ECHR, Lingens $v$. Österreich, ECtHR Application No. 9815/82, Judgment of 8 July 1986, para. 42; see Hinghofer-Szalkay, S. (2012), "Extreme Meinungen und Meinungsäußerungsfreiheit: Die Schranke des Artikel 17 EMRK”, Journal für Rechtspolitik 20(2), 106-114.

90 Frowein, J.A. (2009), "Article 18" In: J.A. Frowein and W. Peukert (eds), EMRKKommentar ( $3^{\text {rd }}$ ed.). Kehl am Rhein / Strasbourg / Arlington: N. P. Engel Verlag, para. 2; Keller, H. and Heri, C. (2016), "Selective criminal proceedings and article 18 ECHR: The European Court of Human Rights' untapped potential to protect democracy", Human Rights Law Journal 37, 1-10, 2 et seq.

91 On the pre-Merabishvili (Grand Chamber) case law, see Harris et al, supra note 68, 844.

92 Gusinskiy v. Russia, ECtHR Application No. 70276/01, Judgment of 19 May 2004. 
countries in Eastern Europe and the Caucasus. The decisions often concerned measures that were symptomatic of authoritarian tendencies. Thus, the Merabishvili, Tymoshenko and Lutsenko cases concerned the imprisonment of prominent opposition politicians. In the Jafarov and Mammadov $v$. Azerbaijan cases, political dissenters were silenced by measures under criminal law. ${ }^{93}$

At the outset, however, the Court stressed that there was still a presumption that these Convention States were acting in good faith, i.e., that they were in principle complying with the treaty. ${ }^{94}$ In procedural terms, this meant that the applicant not only had to bear the full burden of proof but that the Court also imposed strict requirements, ${ }^{95}$ permitting neither prima facie proof ${ }^{96}$ nor a reversal of the burden of proof. ${ }^{97}$ After considerable criticism, ${ }^{98}$ the Court then became more liberal: in the Lutsenko, Tymoshenko and Mammadov cases, the Court went for a more contextual approach and no longer required direct proof of a corresponding State motive. ${ }^{99}$ In the Jafarov case, it took into account the general situation of human rights activists. The evidence of systemic problems in Azerbaijan thus facilitated the determination of a concrete violation of Article 18 ECHR. ${ }^{100}$

93 Merabishvili v. Geogia, ECtHR Application No. 72508/13, Judgment of 28 November 2017; Tymoshenko v. Ukraine, ECtHR Application No. 49872/11, Judgment of 30 April 2013; Lutsenko v. Ukraine, ECtHR Application No. 6492/11, Judgment of 3 July 2012; Jafarov v. Azerbaijan, ECtHR Application No. 69981/1, Judgment of 17 March 2016; Mammadov v. Azerbaijan, ECtHR Application No. 15172/13, Judgment of 22 May 2014; see also Cebotari v. Moldova, ECtHR Application No. 35615/06, Judgment of 13 November 2007; extensively Keller and Heri, supra note 90, 3 et seq.

94 Mammadov v. Azerbaijan, supra note 93, para. 137; Lutsenko v. Ukraine, supra note 93, para. 106; Khodorkowski v. Russia, ECtHR Application No. 5829/04, Judgment of 31 May 2011, para. 255.

95 Lutsenko v. Ukraine, supra note 93, para. 107; Khodorkowski v. Russia, supra note 94, para. 256; Cebotari v. Moldova, supra note 93, paras 52 et seq.

96 E.g., Varnava and others v. Turkey, ECtHR Application No. 16064/90, Judgment of 18 September 2009, paras 182-184.

97 Khodorkowski v. Russia, supra note 94, para. 256.

98 Tan, F. (2018), "The Dawn of Article 18 ECHR: A Safeguard Against European Rule of Law Backsliding?", Goettingen Journal of International Law 9(1), 109-141, 127 et seq.; Keller and Heri supra note 90, 8.

99 Mammadov v. Azerbaijan, supra note 93, para. 137; Tymoshenko v. Ukraine, supra note 93, para. 294; Lutsenko $v$. Ukraine, supra note 93, paras 104 et seq.

100 Jafarov $v$. Azerbaijan, supra note 93, paras 104, 159-163. 
The Chamber decision in the Mammadov case also triggered the first proceedings under Article 46 para. 4 ECHR. In a recent decision rendered unanimously, the Grand Chamber of the ECtHR - in agreement with the Council of Ministers - stated that Azerbaijan had not implemented the judgment and thus had violated its obligations under the Convention. ${ }^{101}$ The Court admitted that its first Mammadov ruling was declaratory and remained silent on the question of suitable individual measures. However, the absence of an explicit statement relevant for execution in the first Mammadov judgment was not decisive for the question whether Azerbaijan had breached its obligations under Article 46 para. 1 ECHR. In any event, the measures taken by the defendant must be "compatible with the conclusions and spirit of the Court's judgment" 102 . With this ruling, the Court sends a strong signal: even if a judgment is silent on individual remedies, this provides no defense for the defendant State. A restitutio in integrum in the form of release from custody cannot be refused if a conviction has been handed down on the basis of Article 18 ECHR and a Convention State has acted in bad faith. ${ }^{103}$ Nevertheless, the judgment was subject to criticism: the added value of the proceedings was claimed to be minimal, while the risks to the legitimacy of the Court were considerable. ${ }^{104}$

The Court took a further step in its judgment in the Merabishvili case, ${ }^{105}$ in which the Grand Chamber completely departed from the stricter requirements on proof under Article 18 ECHR. The Court held that the "usual approach to proof rather than special rules" "can and should" be applied. ${ }^{106}$ Thus, the burden of proof is no longer borne exclusively by one party, and the Court can investigate ex officio. ${ }^{107}$ This lowered standard increases the practical relevance of Article $18 \mathrm{ECHR} .{ }^{108}$ Furthermore, the

101 Mammadov v. Azerbaijan, supra note 10.

102 Ibid., para.186.

103 Çalı, B. (2019), "No Going Nuclear in Strasbourg: The Infringement Decision in Ilgar Mammadov v. Azerbaijan by the European Court of Human Rights”, Verfassungsblog, 30 May, available at https://verfassungsblog.de/no-going-nuclear-in-stra sbourg/, accessed 3 December 2019.

104 De Londras, F. and Dzehtsiarou, K. (2017), "Mission Impossible? Addressing Non-Execution through Infringement Proceedings in the European Court of Human Rights”, International \& Comparative Law Quarterly 66(2), 467-490, 486 et seq.

105 Merabishvili v. Georgia, supra note 93. See Çal1, supra note 1, 267 et seq.; Tan, supra note 98,133 et seq.

106 Merabishvili v. Georgia, supra note 93, para. 310.

107 Ibid., para. 311.

108 See also Tan, supra note 98, 135. 
Court strengthened the relevance of Article 18 ECHR by emphasizing the autonomous character of the norm. Although Article 18 ECHR still only becomes operative in conjunction with other provisions of the Convention, it now has autonomous significance insofar as it prohibits the Convention States from restricting Convention rights for purposes contrary to the Convention. ${ }^{109}$ Here, the criterion of the "predominant purpose" of a measure introduced in the Merabishvili case appears to be problematic. ${ }^{110}$ It seems as if the Court will tolerate abusive purposes as long as the legitimate purpose of the restriction of rights prevails. ${ }^{111}$

It will remain a challenge for complainants under Article 18 ECHR to make their case. ${ }^{112}$ For example, in the Navalnyy and Ofitserov case, ${ }^{113}$ the ECtHR established a new requirement regarding the application of Article 18 ECHR: in examining the violation of Article 6 of the ECHR, it acknowledged that there was an obvious link between the complainant's public activities and the decision of the investigative committee in bringing charges against him. ${ }^{114}$ Nevertheless, it rejected the complaint as inadmissible, arguing that Article 18 ECHR cannot be asserted in conjunction with Article 6 and Article 7 ECHR. ${ }^{115}$ This development of the case law was rightly received with disapproval. ${ }^{116}$

\section{The Exhaustion of Domestic Remedies}

It is a truism that red lines should be drawn as early as possible in order to have an effect. But the ECtHR must also respect its subsidiarity. According to Article 35 para. 1 ECHR, the ECtHR may only deal with a matter after

109 Merabishvili v. Georgia, supra note 93, paras 287-288.

110 Ibid., para. 353.

111 For criticism in this regard, see the joint concurring opinion of Judges Yudkivska, Tsotsoria and Vehabović on Merabishvili v. Georgia, supra note 93, paras 1, 19, 37; also concurring opinion of Judge Serghides in the same matter, paras 3, 34; joint concurring opinion of Judges Sajó, Tsotsoria and Pinto De Albuquerque on Tchankotadze v. Georgia, ECtHR Application No. 15256/05, Judgment of 21 June 2016, para. 1.

112 On this jurisprudence, see Keller and Heri, supra note 90, 6.

113 Navalnyy and Ofitserov v. Russia, ECtHR Application No. 46632/13, Judgment of 23 February 2016.

114 Ibid., para. 119.

115 Ibid., para. 129.

116 Ibid., separate opinion of Judges Nicolaou, Keller and Dedov; Keller and Heri, supra note 90, 6 . 
all domestic remedies have been exhausted. The corresponding dilemma can be seen clearly in the Court's reactions to the Turkish repressions that began in 2016. After receiving numerous complaints against repressive measures applied during the attempted coup, the Court initially dismissed such complaints as inadmissible in the Mercan ${ }^{117}$, Catal ${ }^{118}$, Zibni ${ }^{119}$, and Köksal ${ }^{120}$ cases. The complainants, the Court argued, had not exhausted domestic remedies ${ }^{121}$ because the decisions of the Turkish Constitutional Court were still pending. This has likewise led to criticism. ${ }^{122}$

According to its case law, the Court may indeed decide if the legal remedy to be lodged is futile or ineffective. ${ }^{123}$ The issue, therefore, hinged on the question of whether the Turkish courts - including the Constitutional Court - had remained functioning institutions. In the Altan ${ }^{124}$ and Alpay ${ }^{125}$ cases, the ECtHR, in agreement with the Turkish Constitutional Court, found that the detention of two journalists violated their rights under Articles 5 paras 1 and 10 ECHR. Under these circumstances, and in accordance with the principle of subsidiarity, the stance of the ECtHR seems plausible, especially as its cooperation with national courts is key to fulfilling its mandate.

\section{The Procedural Margin of Appreciation}

A club can only be strong and vibrant if its members act in its spirit. Accordingly, the procedures and doctrines that link supranational courts to national courts are key. Thus, the Court of Justice of the EU can avail itself of the preliminary ruling procedure as developed since van Gend en Loos, while the IACtHR benefits from the conventionality control introduced in

117 Mercan v. Turkey, ECtHR Application No. 56511/16, Decision of 8 November 2016.

118 Catal v. Turkey, ECtHR Application No. 2873/17, Decision of 7 March 2017.

119 Zihni v. Turkey, ECtHR Application No. 59061/16, Decision of 29 November 2016.

120 Köksal v. Turkey, ECtHR Application No. 70478/16, Decision of 6 June 2017.

121 Different in Er a.o. v. Turkey, ECtHR Application No. 23016/04, Judgment of 31 July 2012, paras 45 et seq.

122 Frowein, J.A. (2017), "Straßburg muss handeln", Frankfurter Allgemeine Sonntagszeitung, 3 March 2017.

123 On the exhaustion of domestic remedies, see especially Vučković a.o. v. Serbia, ECtHR Application No. 17153/11, Judgment of 25 March 2014, paras 69 et seq.

124 Altan v. Turkey, supra note 74.

125 Alpay $v$. Turkey, supra note 75. 
Almonacid Arellano. ${ }^{126}$ For a long time, the ECtHR lacked a comparable tool. However, the procedural margin of appreciation doctrine offers something comparable. ${ }^{127}$ It could readjust the Court's mandate and substantiate its claim to speak the law In the name of the European club of liberal democracies.

The core idea is that the ECtHR will exercise restraint if the national decision at issue adequately considers the relevant case law of Strasbourg. This is based on the margin-of-appreciation doctrine, ${ }^{128}$ according to which the Convention States have discretion concerning the interpretation and application of a Convention norm in many, albeit by no means all, case constellations. The doctrine is justified by the subsidiarity of the Convention system, ${ }^{129}$ the greater democratic legitimacy of the Convention States' legislatures ${ }^{130}$ and the greater proximity of the national authorities to the subject matter. ${ }^{131}$

126 See Weiler, J.H.H. (1991), "The Transformation of Europe”, Yale Law Journal 100(8), 2403-2483, 2420 et seq.; Ferrer MacGregor, E. (2017), "The Conventionality Control as a Core Mechanism of the Ius Constitutionale Commune" In: von Bogdandy et al., supra note 57, 321-336.

127 There is also the advisory opinion procedure under the $16^{\text {th }}$ Additional Protocol which has, however, only been ratified by 13 States (Stand: 19.9.2019).

128 See Marckx v. Belgium, ECtHR Application No. 6833/74, Judgment of 13 June 1979, Dissenting Opinion of Judge Fitzmaurice, paras 27 et seq.; Animal Defenders International v. United Kingdom, Application No. 19010/07, Judgment of 22 April 2013, paras 102, 123; X a.o. v. Austria, ECtHR Application No. 19010/07, Judgment of 19 February 2013, para. 102; scholarship includes Bernhardt, R. (1983), "Internationaler Menschenrechtsschutz und nationaler Gestaltungsspielraum" In: R. Bernhard (ed.), Festschrift für Hermann Mosler. Berlin / New York: Springer, 75-88, 81 et seq.; Frowein, J. (1980), “Die Europäische Menschenrechtskonvention in der neueren Praxis der Europäischen Kommission und des Europäischen Gerichtshofs für Menschenrechte", Europäische Grundrechte-Zeitschrift, 231-237, 237; Spielmann, D. (2012), "Allowing the Right Margin: The European Court of Human Rights and the National Margin of Appreciation Doctrine; Waiver of Subsidiarity of European Review?", Cambridge Yearbook of European Legal Studies 14, 381-418; Binder, C. (2015), "The Concept of the Margin of Appreciation", Journal für Rechtspolitik 23(1), 56-66; Asche, J. (2018), Die Margin of Appreciation. Heidelberg: Springer.

129 Villiger, M. (2007), "The Principle of Subsidiarity in the European Convention on Human Rights” In: M. Kohen (ed.), Promoting Justice, Human Rights and Conflict Resolution through International Law - Liber Amicorum Caflisch. Leiden: Brill, 623-637, 632.

130 S.A.S. v. France, ECtHR Application No. 43835/11, Judgment of 1 July 2014, para. 129; Asche, supra note 128, 44.

131 Handyside v. United Kingdom, supra note 27, para. 48; Jacubowski v. Germany, Application No. 15088/89, Judgment of 23 June 1994, paras 26 et seq. 
The margin of appreciation doctrine was of great interest to the ministers of justice in Copenhagen. In the first public draft of the Copenhagen Declaration of February 2018, the emphasis on the subsidiarity of the ECtHR read like a systemic criticism of its jurisprudence. ${ }^{132}$ The harsh tone probably displeased many and obviously led to fundamental discussions. This is reflected in the Copenhagen Declaration which was adopted in April 2018 and underlines that a strengthening of the subsidiarity principle is not intended to restrict European human-rights protection. ${ }^{133}$ But it nevertheless emphasizes, "[w]here a balancing exercise has been undertaken at the national level in conformity with the criteria laid down in the Court's jurisprudence, the Court has generally indicated that it will not substitute its own assessment for that of the domestic courts, unless there are strong reasons for doing so" 134 . This emphasizes how the margin of appreciation doctrine demands responsibility from the national institutions but at the same time preserves the ultimate responsibility of the ECtHR. ${ }^{135}$

Similar to the preliminary ruling procedure under Article 267 TFEU and the conventionality control of the IACtHR, the margin of appreciation can lead to a more intensive cooperation between the ECtHR and the national courts, thereby ultimately strengthening European human rights protection. In essence, it offers the national courts an incentive to recognize ECtHR jurisprudence as providing authoritative precedents for their decisions. Such a doctrine integrates ECtHR case law deeply into the national legal systems and thus increases its effectiveness. In doing so, it strengthens the club of European democracies and counteracts the criticism of an excessively invasive ECtHR. Of course, it diminishes the role of the ECtHR as a primary driving force in the development of human rights. However, such correction of its mandate seems appropriate because dynamic judicial protection of individual rights, a rarity in the 1970s, has become a regular occurrence in most European legal systems. ${ }^{136}$

132 See Draft Copenhagen Declaration, 5 February 2018, para. 22, available at https:/ /menneskeret.dk/sites/menneskeret.dk/files/media/dokumenter/nyheder/draft_c openhagen_declaration_05.02.18.pdf, accessed 5 December 2019.

133 Copenhagen Declaration, supra note 4, paras 26 et seq.

134 Ibid., para. 28c (emphases added by the authors).

135 Cf. ibid., para. 10.

$136 C f$. the contributions of von Bogdandy, A. / Grabenwarter, C. / Huber, P., Behrendt, C., Farahat, A., Tuori, K., Jouanjan, O., Bifulco, R. / Paris D., Besselink, L., Grabenwarter, C., Tuleja, P. and Amaral, M.L. / Pereira, R.A., Biaggini, G., Requejo Pagés J.L., Sólyom, L., Murkens, J. and Quint, P. In: A. von Bogdandy, C. Grabenwarter and P. Huber (eds) (2016), Handbuch Ius Publicum 
This doctrine is also promising in view of the alienation of some Convention States from the jurisprudence of the ECtHR. These States often refer to the values of national identity, national diversity and national democracy. The margin of appreciation doctrine could take these values into account while at the same time protecting what is essential.

\section{Do the Bundesverfassungsgericht and the Corte Costituzionale frustrate the} pursuit of this mandate?

But which ECtHR decisions have authoritative effects vis-à-vis national courts? ${ }^{137}$ There are many possible gradations. ${ }^{138}$ A controversial dialogue within the network of European constitutional courts has developed on this key issue.

The ECtHR has always claimed that its decisions are authoritative beyond the concrete case. ${ }^{139}$ The Convention States expressly acknowledge such relevance in the Copenhagen Declaration. ${ }^{140}$ However, the Court has recently adopted a particularly categorical position: "[t]he Court would emphasise that its judgments all have the same legal value. Their binding nature and interpretative authority cannot therefore depend on the formation by which they were rendered." ${ }^{141}$ It does not distinguish between a decision of a single judge, a committee of three judges, a chamber of seven judges or the Grand Chamber of seventeen judges, nor between a new development and a doctrine that has been consolidated by several decisions in different formations. It bears mentioning, moreover, that EU law supports this stance of the ECtHR. ${ }^{142}$ However, the German Bundesverfas-

Europaeum. Vol. VI: Verfassungsgerichtsbarkeit in Europa: Institutionen. Heidelberg: C.F. Müller.

137 On the general phenomenon, see the contribution in von Bogdandy, A. and Venzke, I. (eds) (2012), International Judicial Lawmaking. Heidelberg: Springer.

138 Jacob, M. (2014), Precedents and Case-based Reasoning in the European Court of Justice. Cambridge: Cambridge University Press, 218-219. Generally on the functioning of precedents, see Payandeh, M. (2017), Judikative Rechtserzeugung. Theorie, Dogmatik und Methodik der Wirkung von Präjudizien. Tübingen: Mohr Siebeck, 11 et seq.

139 Ireland $v$. United Kingdom, supra note 7, para. 154.

140 See Copenhagen Declaration, supra note 4, para. 26.

141 G.I.E.M. S.R.L. a.o. v. Italy, supra note 7, para. 252.

142 See recital 32 of the Dublin III Regulation (Regulation No. 604/2013 of the European Parliament and of the Council of 26 June 2013 establishing the criteria and mechanisms for determining the Member State responsible for examin- 
sungsgericht and the Italian Corte Costituzionale take a much more differentiated view.

\section{A. Domestic Buffering of the ECtHR's Authority}

According to both these courts, Strasbourg's law making authority is subject to a number of prerequisites and limits. The ruling of the Bundesverfassungsgericht on the ban on strike action by civil servants is a landmark decision in this matter. ${ }^{143}$ According to the decision, German law can only be interpreted in accordance with the Convention "[i]f German courts have latitude for interpreting and balancing within the scope of recognised methods of the interpretation of laws"144. German courts may not "schematically alig[n]" 145 individual constitutional concepts, but must integrate the ECHR "as carefully as possible into the existing, doctrinally differentiated national legal system" 146 by means of an "active process (of acknowledgment)"147. Cases in which the Federal Republic of Germany was not a party must be considered in a context-sensitive manner. ${ }^{148}$ Moreover, not every Strasbourg decision has authority for German courts. Rather, they have to "identify statements regarding principal values enshrined in the Convention and address them" ${ }^{149}$, but not more. This is

ing an application for international protection lodged in one of the Member States by a third-country national or a stateless person, OJ L 180/31, 29 June 2013).

143 On this judgment, see, e.g., Polakiewicz, J. and Suominen-Picht, I. (2018), "Aktuelle Herausforderungen für Europarat und EMRK: Die Erklärung von Kopenhagen (April 2018), das Spannungsverhältnis zwischen EMRK und nationalen Verfassungen und die Beteiligung der EU an dem europäischen Menschenrechtskontrollmechanismus", Europäische Grundrechte-Zeitschrift 45, 383390, 385 et seq.; Jacobs, M. and Payandeh, M. (2019), "Das beamtenrechtliche Streikverbot: Konventionsrechtliche Immunisierung durch verfassungsgerichtliche Petrifizierung", Juristenzeitung 74(1), 19-26.

144 Bundesverfassungsgericht, supra note 3, para. 133.

145 Ibid., para. 131.

146 Ibid., para. 135, with reference to the decisions BVerfGE 111, 307, 327 and VerfGE 128, 326, 371.

147 Ibid., para. 131.

148 Ibid., para. 132; Kaiser, A.-B. (2017), "Streikrecht für Beamten - Folge einer Fehlrezeption?”, Archiv des öffentlichen Rechts 142(3), 417-441, 432 et seq.

149 Bundesverfassungsgericht, supra note 3, para. 132 (emphasis added by the authors). 
far removed from the precedential authority that the Bundesverfassungsgericht assigns to its own decisions. ${ }^{150}$

Similar limits can be found in the more recent case law of the Italian Corte Costituzionale. In 2015, it decided that the ordinary courts would only have to observe Strasbourg case law if Italy had been a party to the lawsuit or if the case law was "consolidated" or consisted of pilot judgments, since only these are generally binding. ${ }^{151}$ Interpretation in conformity with the constitution must otherwise take precedence over interpretations in conformity with the Convention, and there is no obligation to initiate a judicial review proceeding before the Constitutional Court.

This jurisprudence has subjected the Corte Costituzionale to much criticism from scholars ${ }^{152}$ as well as from the ECtHR itself. ${ }^{153}$ If Italian courts now decide what is "consolidated law", this might have negative effects on Italian compliance with the ECHR and even on international legal certainty. ${ }^{154}$ If all courts - and no longer just the Corte Costituzionale - can rule on the authority of Strasbourg's case law, ordinary courts might be overburdened, ${ }^{155}$ as lower court judges usually do not possess enough knowledge about the case law of the ECtHR. Finally, the Constitutional Court threatens to remove itself from the dialogue between the ECtHR and national courts.

The Bundesverfassungsgericht does not make such a distinction. So far, it has dealt with relevant Strasbourg rulings regardless of whether they were issued by the Grand Chamber or only a Chamber. ${ }^{156}$ However, its case law, which only binds German courts to pronouncements on principal values of

150 Extensively Payandeh, Judikative Rechtserzeugung, supra note 138, 373 et seq.

151 Decision No. 49 of 26 March 2015, para. 7; on this decision, see Paris, D. and Oellers-Frahm, K. (2016), “Zwei weitere völkerrechts 'unfreundliche' Entscheidungen des italienischen Verfassungsgerichtshofs aus dem Jahr 2015 (Nr. 49 und 50): Zur Frage der Maßgeblichkeit der Rechtsprechung des EGMR", Europäische Grundrechte-Zeitschrift 43(10-12), 245-252, 247 et seq.; Viganò, F. (2015), "La Consulta e la tela di Penelope", Diritto Penale Contemporaneo 2, 333 343.

152 Bignami, M. (2015), "Le gemelle crescono in salute: la confisca urbanistica tra Costituzione, CEDU e diritto vivente", Diritto Penale Contemporaneo (2), 288-302.

153 G.I.E.M. S.R.L. a.o. v. Italy, supra note 7, para. 252; see also separate opinion of Judge Pinto de Albuquerque, paras 57 et seq.

154 Paris and Oellers-Frahm, supra note 151, 249.

155 Tega, D. (2015), "La sentenza della Corte costituzionale n. 49 del 2015 sulla confisca: 'il predominio assiologico della Costituzione sulla CEDU', Quaderni Costituzionali 2, 400-404.

156 E.g., Bundesverfassungsgericht, supra note 3, paras 163 et seq. 
the Convention, leads to a similar buffering of the authority of Strasbourg's legal production.

\section{B. Legitimacy through Control}

At first glance, this case law of the Corte Costituzionale and the Bundesverfassungsgericht does not appear to be very Convention-friendly. It cannot be denied that it poses a considerable risk to the compliance with the ECHR and Strasbourg's case law. ${ }^{157}$ Criticism and rejection of its judgments can damage the authority of the ECtHR, after all. At the same time, however, this case law also provides an opportunity to share the burden of legitimacy.

The ECtHR has a democratic mandate to not only resolve a dispute for the parties but also promote liberal democracy In the name of the European club of liberal democracies. Nevertheless, the democratic legitimacy of its decisions is often weak, especially when the Court uses open-ended human rights norms to adjudicate controversial or complex domestic issues in sweeping terms. The openness of the national legal systems not only to the abstract provisions of the ECHR but also to the ECtHR's judgments imposes an enormous burden on democratic legitimacy.

Against this background, the weakening of the ECtHR's authority through "buffering" national jurisprudence turns out to be a possible legitimatory asset that supports the pursuit of its mandate. If domestic courts are not strictly bound to Strasbourg precedents, they contribute their own democratic legitimacy when they refer to the ECtHR's decisions. ${ }^{158}$ In addition, a genuine dialogue with the ECtHR, which all sides regard as indispensable, can only develop if the domestic courts can exercise control over the case law they choose to respect. By receiving and discussing Strasbourg's decisions, the national courts affirm the ECtHR's legitimacy.

157 See, for example, the problematic recycling of ECtHR-critical decisions from Germany and Italy by the Russian Constitutional Court (Decision of 14 July 2015, No. 21-P). Regarding this decision, Hartwig, M. (2017), "Vom Dialog zum Disput? Verfassungsrecht vs. Europäische Menschenrechtskonvention - Der Fall der Russländischen Föderation”, Europäische Grundrechte-Zeitschrift 44, 1-23, 8 et seq.

158 On the legitimizing function of the highest national courts, see von Bogdandy, A., Grabenwarter, C. and Huber, P. (2016), "Verfassungsgerichtsbarkeit im europäischen Rechtsraum" In: von Bogdandy, Grabenwarter and Huber, supra note $136, \mathbb{S} 95$, paras $15,17$. 
Of course, this mechanism only works if all institutions involved are aware of their shared responsibility for the European human rights system and understand themselves as good club members. In their dialogue with the ECtHR, all courts of the Convention States must continue to signal their principled support for the Convention system. This does not mean that they must always give their unqualified consent to Strasbourg's law making. But they must act as loyal members of the club of European democracies, in whose name the ECtHR is pursuing a very difficult mandate indeed. 